\title{
Mining Activities and the Chemical Composition of R. Modonkul, Transbaikalia
}

\author{
Zinaida Ivanovna Khazheeva *, Aleksey Maksimovich Plyusnin, Olga Konstantinovna Smirnova, \\ Elena Georgievna Peryazeva, Dashima Ivanovna Zhambalova, \\ Svetlana Gennadievna Doroshkevich and Viktoriya Valerievna Dabaeva *
}

Geological Institute of SB RAS, Ulan-Ude 670047, Russia; plyusnin@ginst.ru (A.M.P.); meta@ginst.ru (O.K.S.); peryazeva@ginst.ru (E.G.P.); dachima@geo.stbur.ru (D.I.Z.); dorosh@ginst.ru (S.G.D.)

* Correspondence: zkhazh@geo.stbur.ru (Z.I.K.); dv.viktoriya@geo.stbur.ru (V.V.D.)

\begin{abstract}
The Dzhidinsky orefield is located in the Zakamensky district of Buryatia. It is characterized by a high concentration of mineralization in a small area. The ores of the Dzhidinsky economic deposits are complex. This ore field includes Pervomaiskoye Mo, Kholtosonskoe W, and Inkurskoe $\mathrm{W}$ deposits. The catchment basin of the river Modonkul is located in the Dzhidinsky orefield. Mineral resource industry waste is a real threat to the city Zakamensk. Currently, the waste of deposits is located at the floodplain terrace and the watershed of the river Modonkul. In this work, the impact of the drainage mine and tributary Inkur on the formation chemical composition of the river Modonkul is studied. The 80 samples of water and suspended matter were taken from a surface of $0-0.5 \mathrm{~m}$ on seven sites. Physical and chemical parameters were measured at the sampling sites, and chemical composition was analyzed in the laboratory. In the natural background of the river, the major cations are, in decreasing order, $\mathrm{Ca}^{2+}>\mathrm{Mg}^{2+}>\mathrm{Na}^{+}+\mathrm{K}^{+}$, and major anions are, also in decreasing order, $\mathrm{HCO}_{3}{ }^{-}>\mathrm{SO}_{4}{ }^{2-}>\mathrm{Cl}^{-}$. Along the river, the chemical type of water changes from bicarbonate to sulfate across the sulfate-bicarbonate or bicarbonate-sulfate class and from calcium-magnesium across sodium-calcium-magnesium reverse calcium-magnesium group. Total dissolved solids (TDS) increase by a factor of 4.0-4.7 between the upper and mouth of the river. The dissolved and suspended loads were studied in the mixing zone of acid mine and river water. The different hydrochemistry characteristics may result from $\mathrm{Fe}, \mathrm{Al}$, and $\mathrm{Mn}$ hydroxide precipitation. The $\mathrm{pH}$ values and dissolved oxygen cycles could change the uptake of heavy metals on suspended iron and manganese oxides, and the mechanism of removing it in water. River particulates have the potential of regulating heavy metal inputs to aquatic systems from pollution. The ore elements or the heavy metals are removed from the water in two ways: by the runoff of Modonkul and the sedimentation of suspended material at the bottom. The inflow of mine water into the Modonkul river leads to the rare earth elements (REEs) composition with negative cerium and positive europium anomalies.
\end{abstract}

Keywords: acidic mine; changes of the chemistry type; alkaline barrier; dissolve and particulate forms of heavy metals; trace elements and REEs

\section{Introduction}

The Dzhidinsky ore field is located in the watershed of Lake Baikal. The industry center of this orefield is the Zakamensky district of Buryatia (Russia). It is characterized by a high concentration of mineralization in a small area. The ores of the Dzhidinsky economic deposits are complex. This orefield includes Pervomaiskoye Mo, Kholtosonskoe W, and Inkurskoe W deposits [1,2]. Industrial ores of Pervomaiskoye deposit contains (\%): $0.1-0.15 \mathrm{Mo} ; 0.018 \mathrm{BeO} ; 0.031 \mathrm{WO}_{3} ; 0.024 \mathrm{Cu} ; 0.038 \mathrm{Zn} ; 0.04 \mathrm{~Pb}$. The ores of the Inkurskoe and Kholtosonskoe deposits are similar in mineral composition but differ in 
the content of useful components. This deposits contains (\%): $0.14-0.7 \mathrm{WO}_{3} ; 0.02-0.56 \mathrm{~Pb} ; 0.04-0.38 \mathrm{Zn}$; 0.03-0.17 Cu; 0.003-0.01 Bi; 0.02-0.05 Be; 4.2-7.6 F; up to $175 \mathrm{~g} / \mathrm{t} \mathrm{Ag;} \mathrm{up} \mathrm{to} 4 \mathrm{~g} / \mathrm{t} \mathrm{Au} \mathrm{[3].}$

Formation of the stockwork Mo-W mineralization occurred during several hydrothermal stages, which were separated in time by intrusive magmatism. First, the Mo stockwork representing the Pervomaiskoye molybdenum deposit formed along with minor Mo-Be mineralization. After wards, the stockwork of hubnerite-bearing veinlets in the Inkurskoe tungsten deposit formed. This was followed by the formation of the stockwork of hubnerite-bearing veinlets in the Inkurskoe tungsten deposit. The latest stage of ore formation is represented by the quartzhubnerite veins of the Kholtosonskoe tungsten deposit $[1,2]$.

Ore components in slightly lower concentrations are present in the tailing pile of the basin river Modonkul. They are actively involved in migration processes and concentrated on geochemical barriers.

The Dzhidinsky tungsten-molybdenum plant (DVMK) was established in 1934 in the city of Zakamensk. In the early years, its production activity was based on the development of gold-tungsten mining. Since 1939, the Kholtosonskoe plant began to operate underground tungsten mining. The Pervomaiskoye molybdenum plant began to operate in 1941; the Inkurskoe tungsten plant began to operate in 1973. The Dzhidinsky tungsten-molybdenum plant stopped work in 1997 due to unprofitable production in the new economic conditions. During the plant operation, more than 40 million tons of hazardous waste were generated and stored in two tailings (Figure 1). Since 2008, pilot work has been carried out on the recycling of tailings, and a mini-factory has been built. The natural-technogenic system covers an area of more than $100 \mathrm{~km}^{2}$ [4]. It includes the industrial Pervomaiskoye, Inkurskoe, Kholtosonskoe deposits, plants, tailings, mine waters from adits, a metal casting plant (Liteyshchik LLC), urban treatment facilities, and a motor transport area. The listed objects are located in the Modonkul river basin.

Geomorphologically the territory under consideration is located in the southern part of the Mongol-Siberian mountain belt and is confined to the Selengino-Vitimsky linear warping zone. This is the second-order morphostructure of the Mesozoic occurrence with moderate neotectonic activation of the bowels [5]. The relief of the territory is valley (absolute elevations 1040-1100 m), low-mountain (up to $1400 \mathrm{~m}$ ), in the immediate vicinity, the mid-mountain (1700-1800 m) belongs to the system of spurs of the Dzhida ridge.

The feature of the geological structure of the territory is confined to the border of two regional geological structures and represented by carbonate-terrigenic strata of the Lower Paleozoic of the Dzhidinsky synclinorium and intrusions of the Modonkul massif. On the border between them plates of ultrabasic rocks, small bodies of granitoids, among intensely crushed and sedimentary-volcanogenic rocks, are developed. Paleozoic intrusive rocks occupy most of the area. Among them, granites, granosyenites, granodiorites, syenites stand out [6,7].

The valley of the river Modonkul has a symmetrical trough-like transverse profile with a maximum width at the mouth of $1300 \mathrm{~m}$. The water discharge of the river depends on the season of the year; in winter, it is 0.12 to $0.18 \mathrm{~m}^{3} / \mathrm{s}$; in the open channel period, it varies in the range of 0.7 to $3.2 \mathrm{~m}^{3} / \mathrm{s}$. The Modonkul river is characterized by the following hydrological parameters: river length $\mathrm{L}=20 \mathrm{~km}$, catchment area $S=170 \mathrm{~km}^{2}$, average annual water discharge $\mathrm{Q}=0.80 \mathrm{~m}^{3} / \mathrm{s}$, and annual water flow $\mathrm{W}=0.025 \mathrm{~km}^{3}$. Bottom sediment is represented by pebbles, and boulders with sand [8].

The mineral resource industry waste is a real threat to the city Zakamensk. The massif of sands with lower concentrations of ore elements are covered in the soil by the wind, melt, and rainwater. The atmospheric precipitation in this region falls mainly in the summer months $(70 \%-80 \%)$, and there are long multi-day rains. Currently, a concentrated stream of natural and technogenic sand goes to a low terrace and into the floodplain of the river Modonkul. The most significant erosion was caused by the storage of tailings due to the long period of its existence (more than 60 years). As a result, a plume of redeposited sands was formed with a length of $7.5 \mathrm{~km}$, a width of 50 to $500 \mathrm{~m}$, and a height of $2 \mathrm{~m}$, located at the mouth of the Modonkul river. The hill material is not cemented with the section of interbedding sandy and sand-clay matter. Clay and sand-clay interlayers are enriched with sulfides, 
guberite, and scheelite. The hill at the mouth of the river Modonkul is composed mainly of fine-grained sands, had a band lamination, reflecting periodic large spills of water in the delta.

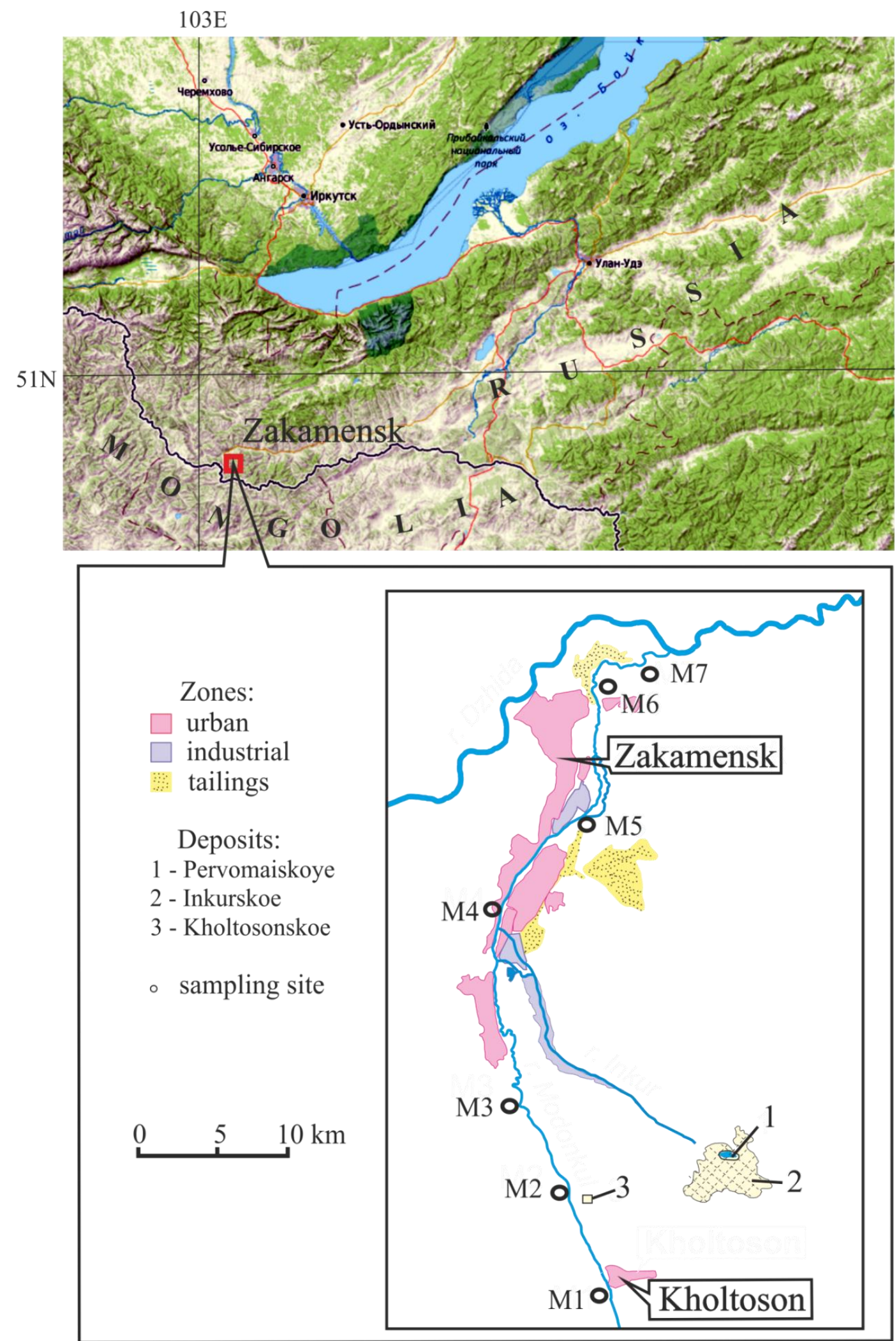

Figure 1. The scheme of the sampling sites. 
The climate of the region is sharply continental, with winds prevailing during the year north-west and north. In winter and spring, the wind speed is $0.3-2 \mathrm{~m} / \mathrm{s}$; in the spring-summer season, the maximum speed is $20 \mathrm{~m} / \mathrm{s}$. In winter, north and north-west winds prevail; in summer, the frequency of east winds increases. The valley of the river Modonkul is characterized by the stagnation of air and a large number of days with calm weather.

\section{Object and Research Methods}

The sampling of water and suspended materials was carried out in the summer period between 2008 and 2014. The sampling sites are shown in Figure 1; their list and locations are summarized in Table 1.

Table 1. Sampling site and their location along r. Modonkul.

\begin{tabular}{cc}
\hline Sample Site & Location \\
\hline M1 & The upper river, village Kholtoson \\
M2 & Below inflow mine water from Kholtosonskoe \\
M3 & Downstream to the city Zakamensk \\
M4 & After inflow tributary Inkur \\
M5 & In the city Zakamensk \\
M6 & After the city Zakamensk \\
M7 & The mouth of river \\
\hline
\end{tabular}

Samples of water and suspended materials were taken at least 1.5-2 $\mathrm{m}$ from the bank at a depth of 0.3 to $0.6 \mathrm{~m}$. Eighty samples were collected along seven sites. The temperature, electrical conductivity, $\mathrm{pH}$, Eh, dissolved oxygen, and total dissolved solids (TDS) were determined at the sampling site. Water samples for trace elements were collected in polyethylene containers $(15 \mathrm{~mL})$ previously prepared in the laboratory by treatment $\mathrm{HNO}_{3} 0.1 \mathrm{~N}$ and washed with deionized water. The water was filtered through Millipore filters $0.45 \mu \mathrm{m}$ pore diameter. After filtration, water samples were preserved by acidification with nitric acid to $\mathrm{pH} \leq 2$.

Particulate forms of elements $(>0.45 \mu \mathrm{m})$ were removed from the filter surface with nitric acid, then dissolved with a mixture of concentrated nitric and sulfuric acids (1:2) and were analyzed by atomic absorption spectrometry. For the selection of a large of suspended sediments, large bottles of water (20-30 L) were taken for subsequent filtration. Analytical work was taken for determination of major anions- $\mathrm{HCO}_{3}{ }^{-}, \mathrm{SO}_{4}{ }^{2-}, \mathrm{Cl}^{-}, \mathrm{F}^{-}, \mathrm{CO}_{3}{ }^{2-}$; cations- $\mathrm{Ca}^{2+}, \mathrm{Mg}^{2+}, \mathrm{Na}^{+}, \mathrm{K}^{+}$; permanganate oxidizability, hardness, $\mathrm{SiO}_{2}$; nitrogen compounds- $\mathrm{NO}_{2}{ }^{-}, \mathrm{NO}_{3}{ }^{-}, \mathrm{NH}_{4}{ }^{+}$; phosphorus compounds- $-\mathrm{P}-\mathrm{PO}_{4}{ }^{3-}, \mathrm{P}_{\text {tot }}$. Analysis of the content of the major ions was carried out in a certified laboratory of the Geological Institute of the SB RAS (Ulan-Ude) according to standard methods for fresh waters [9,10]. Cations (Ca ${ }^{2+}$, $\mathrm{Mg}^{2+}, \mathrm{Na}^{+}, \mathrm{K}^{+}$) were determined by atomic absorption, $\mathrm{F}^{-}, \mathrm{SiO}_{2}$ - by colorimetric, $\mathrm{HCO}_{3}{ }^{-}, \mathrm{CO}_{3}{ }^{2-}$ and $\mathrm{Cl}^{-}$-by titrimetric, $\mathrm{SO}_{4}{ }^{2-}$ - by turbidimetric methods.

The trace and rare earth elements were determined by the ICP-MS method on a double-focusing mass spectrometer, magnetic sector, and an ELEMENT XR cross-flow atomizer (Thermo Finnigan, Bremen, Germany) at the collective use center of the Geological Institute of the SB RAS (Ulan-Ude, Russia). Calibration solutions were prepared by diluting multi-element standard solutions CLMS-1,2,3 (SPEX, Metuchen, NJ, USA). In the preparation of all solutions, deionized water purified by the Elix-3/Milli-Q system (Millipore SAS, Molshein, France) was used. The accuracy of the analysis was monitored using a certified IQC solution (NIST, Walnut, CA, USA). Suspended phase (material $>0.45 \mu \mathrm{m}$ ) was removed from the surface of the filter by treated the mixture of nitric and sulphuric acids (1:2). Then the concentrations of particulate elements were determined using standard atomic absorption analysis methods on an AAC PinAAcle 900F instrument (Perkin Elmer Inc., Waltham, MA, USA). 


\section{Results and Discussion}

\subsection{Main Ions and Total Dissolved Solids (TDS).}

The results of the determination of the major ions and TDS are shown in Table 2. The data of major cations and anions were plotted on the triangle diagram (Figure 2). The cation points on the triangular diagram are located in the small area elongated in the direction of increasing the fraction content of sodium and decreasing the fraction content of alkaline-earth elements. Anion points are located in a narrow area limited by a small fractional content of chloride ions and elongated in the direction of increasing fraction contents of sulfate ions with a decrease in the fraction content of bicarbonate ions (Figure 2).
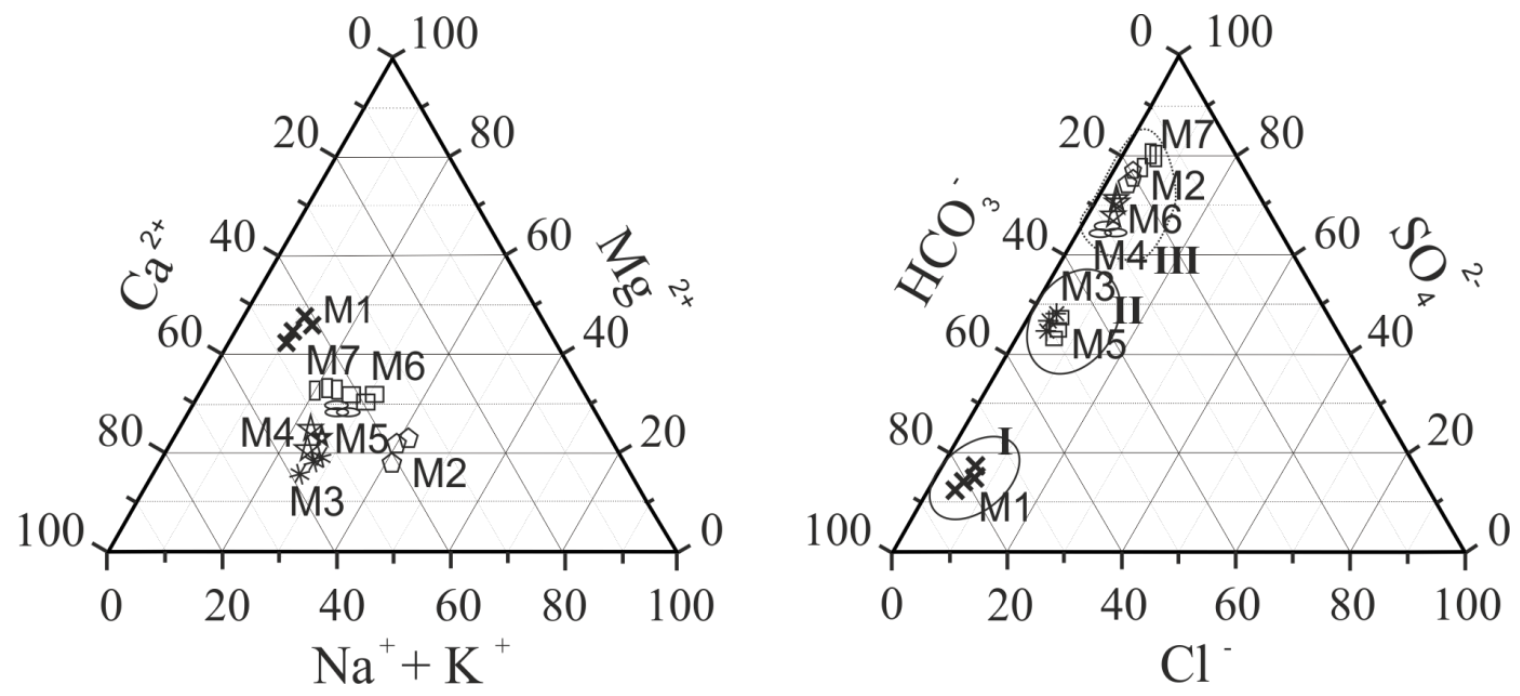

Figure 2. A triangular diagram with the data of the major ions at the sites M1-M7: I-bicarbonate class calcium-magnesium group; II—bicarbonate-sulfate class calcium-sodium group, III—sulphate class calcium-magnesium group.

At the natural background in the upper village Kholtoson (site M1), the water of the Modonkul river is fresh (bicarbonate class calcium-magnesium group). TDS varies $162-180 \mathrm{mg} \cdot \mathrm{L}^{-1}$; the mean is $172 \mathrm{mg} \cdot \mathrm{L}^{-1}$. The average $\mathrm{pH}$ is 7.3 , with the range of variation 7.1-7.6. The fluoride content of $\mathrm{F}^{-}$ ions is $2.72 \mathrm{mg} \cdot \mathrm{L}^{-1}$. The major cations are, in decreasing order, $\mathrm{Ca}^{2+}>\mathrm{Mg}^{2+}>\mathrm{Na}^{+}+\mathrm{K}^{+}$, and major anions are, also in decreasing order, $\mathrm{HCO}_{3}{ }^{-}>\mathrm{SO}_{4}{ }^{2-}>\mathrm{Cl}^{-}$, which is characterized as the natural river waters within the magmatic rocks. Among anions, bicarbonates dominate with the range of variation $100.3-109.6 \mathrm{mg} \cdot \mathrm{L}^{-1}$; the mean value is $106.7 \mathrm{mg} \cdot \mathrm{L}^{-1}$. The fractional content of bicarbonate is $78.5 \%$ eq. On the triangular diagram, the anion points are located in the lower area (Figure 2). The sulfate ion concentration varies in the range $10.5-16.8 \mathrm{mg} \cdot \mathrm{L}^{-1}$ with the mean value of $15.2 \mathrm{mg} \cdot \mathrm{L}^{-1}\left(14.7 \%\right.$ eq), $\mathrm{Cl}^{-}$ chlorides-5.1-6.9 $\mathrm{mg} \cdot \mathrm{L}^{-1}$, the mean value is $6.1 \mathrm{mg} \cdot \mathrm{L}^{-1}(7.1 \% \mathrm{eq})$. Among the cations, predominantly calcium and magnesium account for $87.2 \%$ eq. The concentrations of $\mathrm{Ca}^{2+}$ and $\mathrm{Mg}^{2+}$ vary in the range of variation $19.6-22.5 \mathrm{mg} \cdot \mathrm{L}^{-1}$ (the mean value is $20.1 \mathrm{mg} \cdot \mathrm{L}^{-1}$ ) and $13.6-16.1 \mathrm{mg} \cdot \mathrm{L}^{-1}$ (the mean value is $\left.14.1 \mathrm{mg} \cdot \mathrm{L}^{-1}\right)$, respectively. The concentrations of alkali metals are in the range $5.2-8.4 \mathrm{mg} \cdot \mathrm{L}^{-1}$, the mean value is $6.3 \mathrm{mg} \cdot \mathrm{L}^{-1}$. TDS varies from 169 to $198 \mathrm{mg} \cdot \mathrm{L}^{-1}$. The equivalent ratio of ions is $\left(\mathrm{Ca}^{2+}\right.$ $\left.+\mathrm{Mg}^{2+}\right) / \mathrm{HCO}_{3}{ }^{-}=1.24$. The chemical type is $\mathrm{HCO}_{3}{ }^{-}-\mathrm{Ca}^{2+}-\mathrm{Mg}^{2+}$ (Table 2). 
Table 2. The concentrations of main ions and total dissolved solids (TDS) of the river Modonkul in the period 2008-2014.

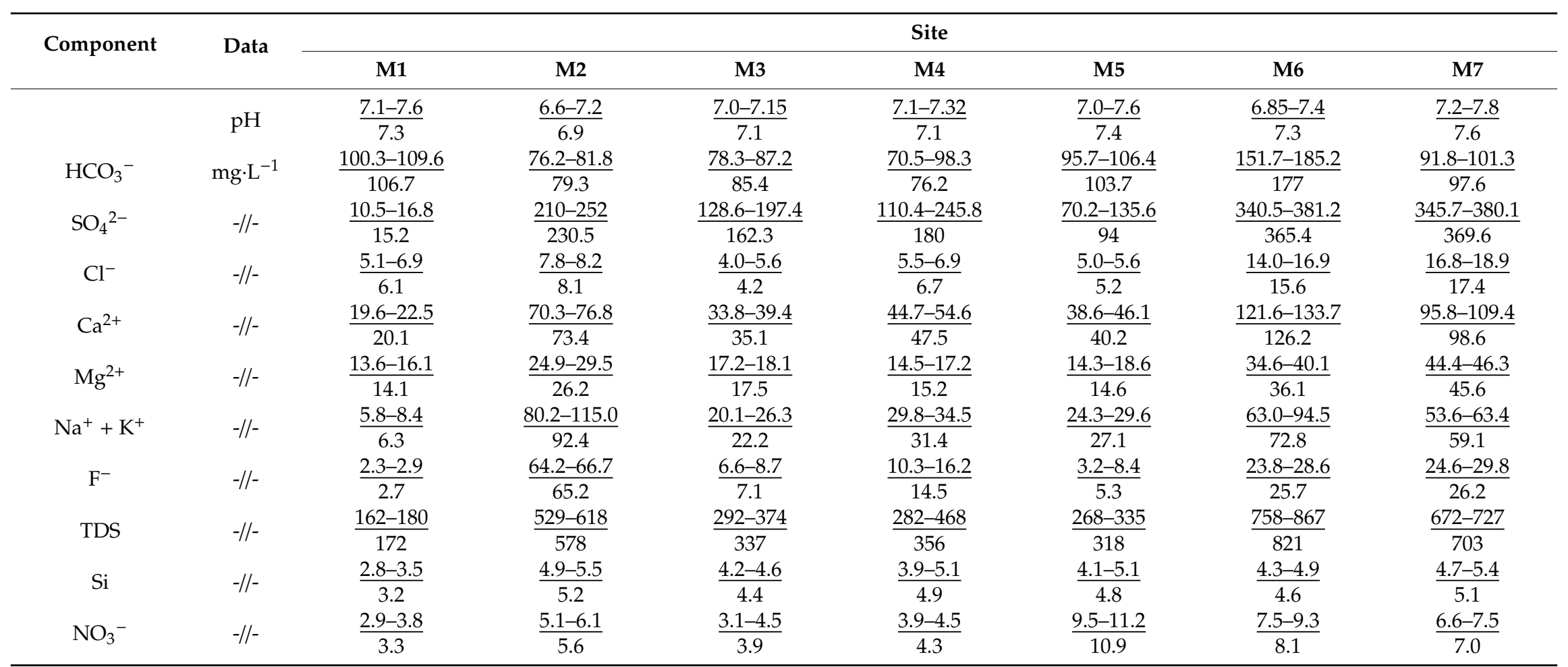

Note. In the numerator-the range of concentrations; in the denominator-the mean value. 
The site M2 is located below flowing the mine water of the Kholtosonskoe deposit. At this site, the water of the river Modonkul is the result of the mixing of natural bicarbonate river water and sulfate acidic water from the adit. In this site, water is characterized as weakly acid-neutral $\mathrm{pH}$ (6.6-7.2), TDS varies $529-618 \mathrm{mg} \cdot \mathrm{L}^{-1}$, mean value is $578 \mathrm{mg} \cdot \mathrm{L}^{-1}$. The sum of major ions increases by almost 3 times. The concentration of the bicarbonate ion $\mathrm{HCO}_{3}{ }^{-}$varies from 76.2 to $81.8 \mathrm{mg} \cdot \mathrm{L}^{-1}$, the equivalent fraction is $19.3 \%-20.5 \%$ eq; the sulfate ion $\mathrm{SO}_{4}{ }^{2-}$-from 210 to $252 \mathrm{mg} \cdot \mathrm{L}^{-1}\left(74.8 \%-76.2 \%\right.$ eq); $\mathrm{Cl}^{-}$ion-from 7.8 to $8.2 \mathrm{mg} \cdot \mathrm{L}^{-1}$ (3.7\%-3.8\% eq), and $\mathrm{Ca}^{2+}$-from 70.8 .3 to $76.8 \mathrm{mg} \cdot \mathrm{L}^{-1}(34.6 \%-36.7 \% \mathrm{eq})$; $\mathrm{Mg}^{2+}$-from 24.9 to $27.5 \mathrm{mg} \cdot \mathrm{L}^{-1}\left(21.6 \%-22.7 \%\right.$ eq); $\mathrm{Na}^{+}$-from 80.2 to $115 \mathrm{mg} \cdot \mathrm{L}^{-1}(39.6 \%-41.5 \%$ eq). The content of $\mathrm{F}^{-}$ion increases by 24.1 times up to $64.2-66.7 \mathrm{mg} \cdot \mathrm{L}^{-1}$. The major cations are, in decreasing order, $\mathrm{Na}^{+}$ $>\mathrm{Ca}^{2+}>\mathrm{Mg}^{2+}$, and the major anions are, also in decreasing order, $\mathrm{SO}_{4}{ }^{2-}>\mathrm{HCO}_{3}{ }^{-}>\mathrm{Cl}^{-}$. The value of the equivalent ratio of ions $\left(\mathrm{Ca}^{2+}+\mathrm{Mg}^{2+}\right) / \mathrm{HCO}_{3}{ }^{-}$is 4.45 . The chemical type was $\mathrm{SO}_{4}{ }^{2-}-\mathrm{Na}^{+}-\mathrm{Ca}^{2+}$. The chemical composition of water belongs to sulfate class sodium-calcium group (Table 2).

In the triangular diagram, the cations are shifted in the direction of an increasing fraction of $\mathrm{Na}^{+}$-cation, the anions are shifted in the direction of an increasing fraction of sulfate-ion, remaining in a narrow area of the fraction of $\mathrm{Cl}^{-}$ion. The concentrations of the sulfate $\mathrm{SO}_{4}{ }^{2-}$ ion increase almost by 15 times, the bicarbonate $\mathrm{HCO}_{3}{ }^{-}$ion decreases by 1.3 times, the alkaline $\mathrm{Na}^{+}$cation increases by 14.6 times, and the alkaline earth $\mathrm{Ca}^{2+}$ and $\mathrm{Mg}^{2+}$ cations increase by 18 to 3.6 times.

At the site M3, downstream up the city Zakamensk, the chemical composition of river water belongs to the bicarbonate-sulfate class of the calcium-sodium group. TDS varies $292-374 \mathrm{mg} \cdot \mathrm{L}^{-1}$, $\mathrm{pH}$ 7.06-7.15. Compared with the previous sampling site, the sum of main ions decreases by 1.7 times, the concentration of sulfate ions—by 1.4; sodium—by 4.1; calcium—by 2; magnesium — by 1.4; fluoride ions-by 9 times but only the bicarbonate ion concentration increases by 1.1 times. The chemical type is $\mathrm{HCO}_{3}{ }^{-}-\mathrm{SO}_{4}{ }^{2-}-\mathrm{Ca}^{2+}-\mathrm{Na}^{+}$.

At the site M4, after the confluence of the tributary Incur, river water belongs to the sulfate-bicarbonate class of the calcium-sodium group. TDS varies $282-468 \mathrm{mg} \cdot \mathrm{L}^{-1}$. The water is neutral, slightly alkaline at $\mathrm{pH}$ 7.1-7.32. Compared with the previous sampling site, the sum of main ions increases by 1.1 times; the concentrations of calcium, magnesium, sodium, sulfate, chloride, and fluoride increase by 1.1 to 1.3 times. The concentration of bicarbonate ion decrease by 1.1 times. The chemical type is $\mathrm{SO}_{4}{ }^{2-}-\mathrm{HCO}_{3}{ }^{-}-\mathrm{Ca}^{2+}-\mathrm{Na}^{+}-\mathrm{Mg}^{2+}$.

At the site M5 in the city Zakamensk, water belongs to the hydrocarbonate-sulfate class of the calcium-magnesium-sodium group. TDS varies $268-335 \mathrm{mg} \cdot \mathrm{L}^{-1}$. The water is slightly alkaline at $\mathrm{pH}$ 7.0-7.6. Compared with the previous sampling site, the concentrations of sulfates, fluorides, calcium decrease by 1.1-2.6 times, but the bicarbonate ion concentration increases by 1.3 times. The chemical type is $\mathrm{HCO}_{3}{ }^{-}-\mathrm{SO}_{4}{ }^{2-}-\mathrm{Ca}^{2+}-\mathrm{Mg}^{2+}-\mathrm{Na}^{+}$.

The site M6 is located 1.2 to $1.5 \mathrm{~km}$ downstream from city Zakamensk, where the discharge of the household sewage is inflowed. In this site, water belongs to the sulfate class of the calcium group. TDS varies $758-867 \mathrm{mg} \cdot \mathrm{L}^{-1}$. The water is $\mathrm{pH}$ 6.8-7.4. Compared with the previous sampling site, the sum of the main ions increases by 2.5 times; the concentration of sulfates, fluorides, and calcium increase by 3.1-4.8 times. In the equivalent contents, the fraction of sulfates and calcium increases by 1.1-1.3 times, and the fraction of the other ions decreases by 1.1-1.6 times. The chemical type is $\mathrm{SO}_{4}{ }^{2-}-\mathrm{HCO}_{3}{ }^{-}-\mathrm{Ca}^{2+}-\mathrm{Na}^{+}$.

The site M7 is located at the mouth of the river, where a fluvial terrace is formed, represented by fine-grained sands and clay materials. The water was slightly alkaline at $\mathrm{pH} 7.2-7.8$. In this site, water belongs to the sulfate class of the calcium-magnesium group. TDS varies $672-727 \mathrm{mg} \cdot \mathrm{L}^{-1}$. The concentration of magnesium increases by 1.2 times and bicarbonates decrease by 1.8 times. The concentration of other ions changes no more than 1.1 times. The chemical type is $\mathrm{SO}_{4}{ }^{2-}-\mathrm{Ca}^{2+}-\mathrm{Mg}^{2+}$.

Compared with the natural background (the upper part of the river), the TDS increases in the site M2-by 3.3, M3-by 1.9, M4-by 2.0, M5-by 1.8, M6-by 4.7, and M7-by 4.0 times. Initially, significant changes in the chemical composition occur in the site M2 after the inflow of mine 
water. In this site, the value of $\mathrm{pH}$ drops to 6.6. Downstream the $\mathrm{pH}$ increases up to 7.8 with the increasing TDS.

The increasing of TDS water is due to a sharp increase of the concentration of sulfate ion and the associated equivalent amounts of cations. Compared with to the natural background the concentration of sulfate ions increases in the site M2-by 15.1, M3-by 10.6, M4-by 11.8, M5-by 6.1, M6-by 24.0, M7-by 24.2 times; bicarbonate ion changes by 1.1-1.6 times; chloride content increases in the site M2-by 1.3, M6 - by 2.5, M7-by 2.8 times. The concentration of $\mathrm{Ca}^{2+}$ ion increases in the site M2-by 3.6, M3-by 1.6, M4-by 2.3, M5-by 2.0, M6-by 6.2, M7-by 4.8 times. The concentration of $\mathrm{Mg}^{2+}$ increases in site M2-by 1.8, M6-by 2.5, M7-by 3.2 times, the concentration of alkali metals increases—by 14.6, M3 - by 3.5, M4—by 4.9, M5—by 4.3, M6—by 11.6, M7—by 9.4 times (Figure 3a). The $\mathrm{F}^{-}$ion concentration increases in the site M2-by 23.8, M3 -by 2.6, M4-by 5.3, M5-by 1.9, M6—by 9.5, M7—by 9.7 times.

a)

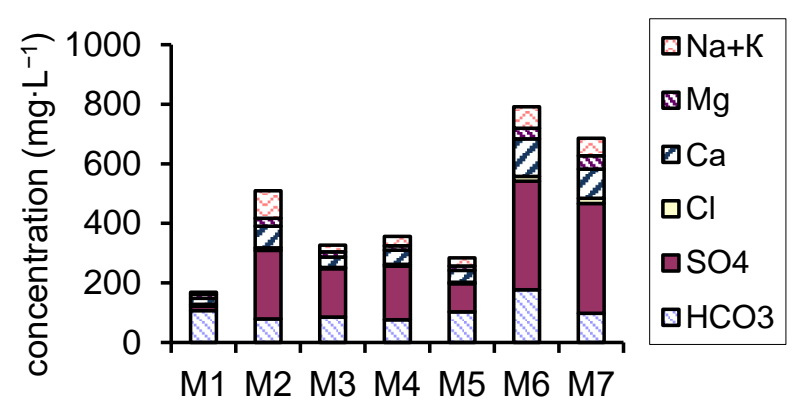

sampling site

b)

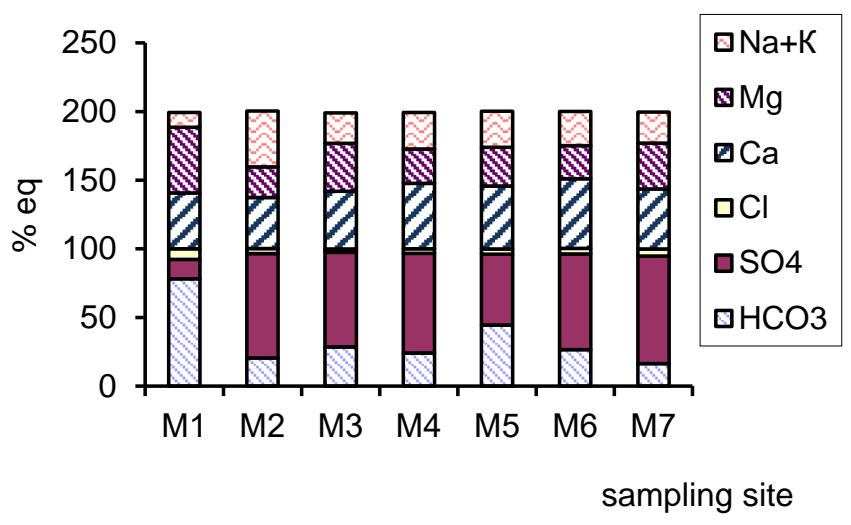

Figure 3. Variation of the concentration major ions (a) and its the equivalent fraction content $(\mathbf{b})$.

Compared with the natural background the equivalent fraction of sulfate ions increases in the site M2—by 5.3, M3-by 4.7, M4-by 5.1, M5—by 3.6, M6-by 4.7, M7-by 5.5 times; bicarbonate ions decrease-by 3.8, M4-by 2.7, M5-by 1.7, M6-by 2.9, M7-by 4.7 times; the fractional contents of chloride ion decrease by 1.5-3.1 times. The fractional content of $\mathrm{Na}^{+}$cation increases-by 3.7, M4-by 2.5, M6-by 2.3, M7-by 2.1 times; the content of $\mathrm{Mg}^{2+}$ decreases by 2.1, M4-by 1.8, M6-by 1.9, M7-by 1.4 times; the content of $\mathrm{Ca}^{2+}$ ion changes in different directions, either decreasing or increasing in the range of variation 1.1-1.2 times (Figure 3b).

As is known, the concentration of main $\mathrm{Ca}^{2+}, \mathrm{Mg}^{2+}$ ions depends both on their abundances in the continental crust and their mobility during weathering and transport. The $\mathrm{HCO}_{3}{ }^{-}$concentration 
characterizes by the rate of $\mathrm{CO}_{2}$ absorption from the atmosphere; therefore, in natural river waters, the equivalent ratio is $\left(\mathrm{Ca}^{2+}+\mathrm{Mg}^{2+}\right) / \mathrm{HCO}_{3}{ }^{-} \approx 1[11,12]$. In the case of water, $\mathrm{r}$. Modonkul, as seen in Figure $4 \mathrm{a}$, when the equivalent ratio of ions $\left(\mathrm{Ca}^{2+}+\mathrm{Mg}^{2+}\right) / \mathrm{HCO}_{3}{ }^{-}>2$, the chemical type of river water changes. The variation of the equivalent ratio of ions is positively correlated with TDS (Figure 4a). In addition, along the length of river, the concentration of fluoride ions is positively correlated with the ratio $\left(\mathrm{Ca}^{2+}+\mathrm{Mg}^{2+}\right) / \mathrm{HCO}_{3}{ }^{-}$, as shown in Figure $4 \mathrm{~b}$.

a)

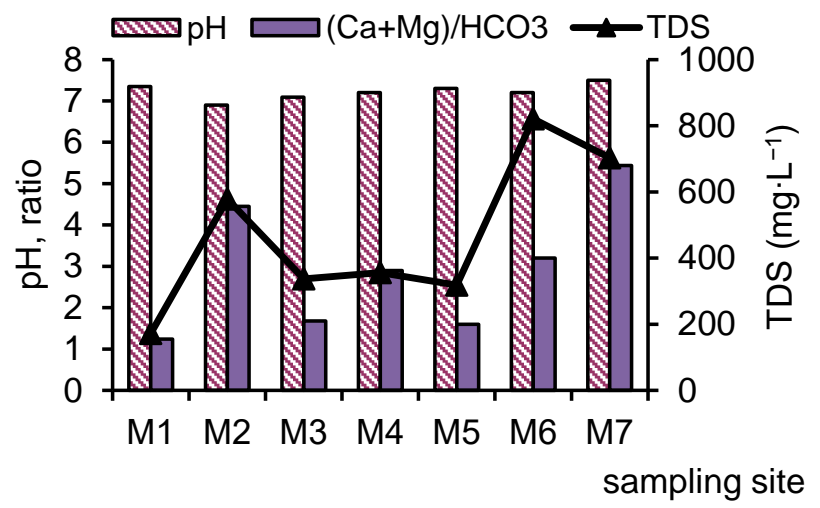

b)

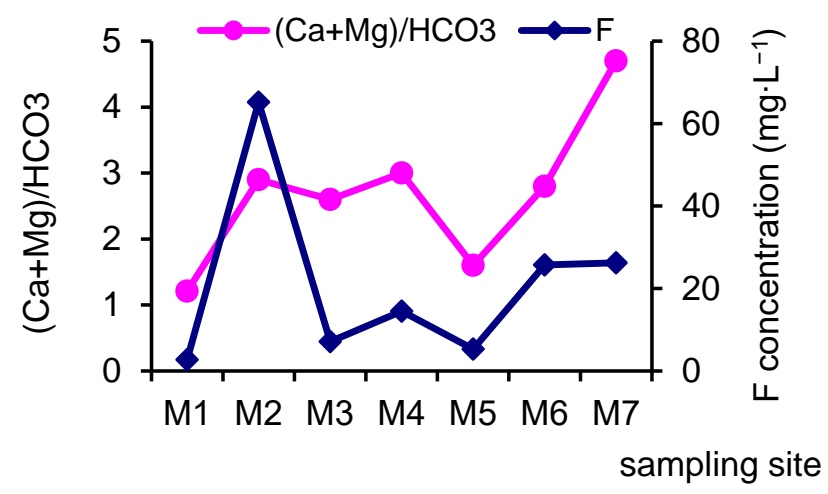

Figure 4. Variation of the equivalent ratio $\left(\mathrm{Ca}^{2+}+\mathrm{Mg}^{2+}\right) / \mathrm{HCO}^{3-}$ with total dissolved solids (TDS), value $\mathrm{pH}(\mathbf{a})$ and with fluoride concentration $(\mathbf{b})$.

Thus, downstream from the M1 to M7 sites, the chemical type of water changes from bicarbonate to sulfate across sulfate-bicarbonate or bicarbonate-sulfate class and from calcium-magnesium across sodium-calcium-magnesium reverse calcium-magnesium group. The river is an open dynamically changing system; the influence of inflowing tributary and mine on the chemical composition occurs along the length.

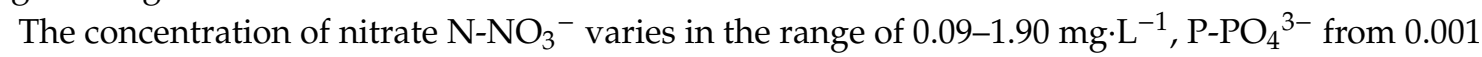
to $0.004 \mathrm{mg} \cdot \mathrm{L}^{-1}$. The concentration of permanganate oxidizability was $2.4-6.2 \mathrm{mg} \cdot \mathrm{L}^{-1}$; and chemical oxygen demand (COD) $-8.2-22.6 \mathrm{mg} \cdot \mathrm{L}^{-1}$. The value of the five-day of biological oxygen demand $\left(\mathrm{BOD}_{5}\right)$ varies from 0.5 to $3.7 \mathrm{mg} \cdot \mathrm{L}^{-1}$.

\subsection{Trace Element}

The results of the mean concentration of trace elements in the river Modonkul are summarized in Table 3. In this table, the mean world concentrations of dissolved trace elements in a number of worldwide rivers are shown from review [13]. 
Table 3. The mean value trace-elements concentrations of the river Modonkul at the sites M1 and M7 ( $n=15$-number of samples) $\left(\mu \mathrm{g} \cdot \mathrm{L}^{-1}\right)$.

\begin{tabular}{|c|c|c|c|c|c|c|c|}
\hline \multirow{2}{*}{ Element } & \multicolumn{2}{|c|}{ Site } & \multirow{2}{*}{$\begin{array}{c}\text { World Mean } \\
\text { Value [13] }\end{array}$} & \multirow{2}{*}{ K1 } & \multirow{2}{*}{ K2 } & \multirow{2}{*}{ K3 } & \multirow{2}{*}{$\begin{array}{c}\text { Detection } \\
\text { Limit }\end{array}$} \\
\hline & M1 & M7 & & & & & \\
\hline $\mathrm{Li}$ & 2.11 & 15.5 & 1.84 & 1.15 & 8.42 & 7.3 & 0.057 \\
\hline $\mathrm{Be}$ & 0.05 & 0.99 & 0.0089 & 5.62 & 111.24 & 19.8 & 0.0027 \\
\hline $\mathrm{Al}$ & 5.6 & 14.6 & 32 & 0.18 & 0.46 & 2.6 & 2.62 \\
\hline Sc & 0.0390 & 0.0136 & 1.2 & 0.03 & 0.01 & 0.3 & 0.0031 \\
\hline $\mathrm{Ti}$ & 0.32 & 0.56 & 0.48 & 0.67 & 1.17 & 1.8 & 0.41 \\
\hline $\mathrm{V}$ & 0.3514 & 0.3252 & 0.71 & 0.49 & 0.46 & 0.9 & 0.0035 \\
\hline $\mathrm{Cr}$ & 1.74 & 1.46 & 0.7 & 2.49 & 2.09 & 0.8 & 0.017 \\
\hline Mn & 6.7 & 483 & 34 & 0.20 & 14.2 & 72 & 0.024 \\
\hline $\mathrm{Fe}$ & 30.4 & 52.7 & 66 & 0.46 & 0.8 & 1.73 & 0.56 \\
\hline Co & 0.1271 & 4.8 & 0.14 & 0.91 & 34.29 & 37.8 & 0.0014 \\
\hline $\mathrm{Ni}$ & 2.34 & 3.53 & 0.801 & 2.92 & 4.41 & 1.5 & 0.024 \\
\hline $\mathrm{Cu}$ & 7.6 & 22.48 & 1.48 & 5.14 & 15.19 & 3.0 & 0.052 \\
\hline $\mathrm{Zn}$ & 11.06 & 216.32 & 0.6 & 18.44 & 360.53 & 19.6 & 0.12 \\
\hline $\mathrm{Ga}$ & 0.0182 & 0.0143 & 0.03 & 0.61 & 0.48 & 0.8 & 0.0135 \\
\hline As & 0.19 & 0.49 & 0.62 & 0.31 & 0.79 & 2.6 & 0.011 \\
\hline $\mathrm{Rb}$ & 1.2 & 4.4 & 1.63 & 0.74 & 2.70 & 3.7 & 0.0087 \\
\hline $\mathrm{Sr}$ & 211.54 & 409.44 & 60 & 3.53 & 6.82 & 1.9 & 0.14 \\
\hline $\mathrm{Y}$ & 0.3596 & 0.0958 & 0.04 & 8.99 & 2.40 & 0.3 & 0.0006 \\
\hline $\mathrm{Zr}$ & 0.1857 & 0.0580 & 0.039 & 4.76 & 1.49 & 0.3 & 0.0052 \\
\hline $\mathrm{Nb}$ & 0.0038 & 0.0032 & 0.0017 & 2.24 & 1.88 & 0.8 & 0.0032 \\
\hline Mo & 2.38 & 6.1500 & 0.42 & 5.67 & 14.64 & 2.6 & 0.057 \\
\hline $\mathrm{Cd}$ & 0.0750 & 4.4 & 0.08 & 0.94 & 55.00 & 58.7 & 0.0016 \\
\hline $\mathrm{Sb}$ & 0.1238 & 0.7829 & 0.07 & 1.77 & 11.18 & 6.3 & 0.0091 \\
\hline Cs & 0.5639 & 0.5250 & 0.011 & 51.26 & 47.73 & 0.9 & 0.0007 \\
\hline $\mathrm{Ba}$ & 69.5014 & 109.09 & 23 & 3.02 & 4.74 & 1.6 & 0.040 \\
\hline Hf & 0.0052 & 0.0056 & 0.0059 & 0.88 & 0.95 & 1.1 & 0.0007 \\
\hline $\mathrm{Ta}$ & 0.0005 & 0.0005 & 0.0011 & 0.45 & 0.45 & 1.0 & 0.0003 \\
\hline W & 0.018 & 0.056 & 0.1 & 0.18 & 0.56 & 3.1 & 0.012 \\
\hline $\operatorname{Re}$ & 0.0031 & 0.0103 & 0.0004 & 7.75 & 25.75 & 3.3 & 0.002 \\
\hline $\mathrm{Pb}$ & 1.19 & 0.9938 & 0.079 & 15.06 & 12.58 & 0.8 & 0.014 \\
\hline Th & 0.0663 & 0.0121 & 0.041 & 1.62 & 0.30 & 0.2 & 0.0023 \\
\hline $\mathrm{U}$ & 2.3 & 3.5 & 0.372 & 6.18 & 9.41 & 1.5 & 0.0011 \\
\hline
\end{tabular}

Note. K1 and K2-ratio of the concentration trace-element at sites M1 and M7 to the world mean value, relatively; K3-ratio of the concentration trace-element at site M7 to the concentration at site M1.

Trace-element concentrations in Modonkul water span 6-7 orders of magnitude. The maximum concentrations within $\mathrm{n} 100 \mu \mathrm{g} \cdot \mathrm{L}^{-1}$ are observed for $\mathrm{Sr}, \mathrm{Mn}, \mathrm{Zn}, \mathrm{Ba}$. The concentrations within $\mathrm{n}$ $10 \mu \mathrm{g} \cdot \mathrm{L}^{-1}$ are typical for $\mathrm{Li}, \mathrm{Al}, \mathrm{Fe}, \mathrm{Cu}, \mathrm{Ba}$; within $\mathrm{n} \mu \mathrm{g} \cdot \mathrm{L}^{-1}$ for $\mathrm{Li}, \mathrm{Al}, \mathrm{Cr}, \mathrm{Mn}, \mathrm{Cu}, \mathrm{Rb}, \mathrm{Pb}, \mathrm{U}, \mathrm{Mo}$; within n $0.1 \mu \mathrm{g} \cdot \mathrm{L}^{-1}$ for Ti, V, Co, As, Y, Zr, Sn, Sb, Cs; within n $0.01 \mu \mathrm{g} \cdot \mathrm{L}^{-1}$ for Be, Sc, Ga, Th, Cd, Y, Zr, W. The remaining elements are present in concentrations not exceeding $n 0.001 \mu \mathrm{g} \cdot \mathrm{L}^{-1}$ (Table 3).

In the natural background (site M1), the mean dissolved concentrations of $\mathrm{Al}, \mathrm{Sc}, \mathrm{V}, \mathrm{Mn}, \mathrm{Fe}, \mathrm{As}$, $\mathrm{Ti}, \mathrm{Rb}, \mathrm{Cd}, \mathrm{Ta}, \mathrm{Hf}, \mathrm{W}$ are 1.1-5.5 times less than that of the world mean values. The mean dissolved concentration of Sc is 33 times less than that of clark. The mean dissolved concentrations of $\mathrm{Be}, \mathrm{Cr}, \mathrm{Ni}$, $\mathrm{Cu}, \mathrm{Zn}, \mathrm{Sr}, \mathrm{Y}, \mathrm{Zr}, \mathrm{Nb}, \mathrm{Mo}, \mathrm{Sb}, \mathrm{Ba}, \mathrm{Re}, \mathrm{Pb}, \mathrm{Th}, \mathrm{U}$ are 1.5-9 times; $\mathrm{Pb}$ and $\mathrm{Zn}$ are 15-18 times; $\mathrm{Cs}$ is 51 times greater than that of world mean values.

In the mouth of the river (site M7), the mean dissolved concentrations of $\mathrm{Al}, \mathrm{V}, \mathrm{Fe}, \mathrm{Ga}, \mathrm{As}, \mathrm{Hf}, \mathrm{Ta}$, $\mathrm{W}$, Th are 1.1-3.3 times, $\mathrm{Sc}-100$ times less than that of the world mean values. The mean dissolved concentrations of $\mathrm{Li}, \mathrm{Cr}, \mathrm{Ti}, \mathrm{Mn}, \mathrm{Co}, \mathrm{Ni}, \mathrm{Cu}, \mathrm{Rb}, \mathrm{Sr}, \mathrm{Y}, \mathrm{Zr}, \mathrm{Mo}, \mathrm{Sb}, \mathrm{Ba}, \mathrm{Re}, \mathrm{Pb}, \mathrm{U}$ are 1.1-25 times; Be is 111 times; $\mathrm{Zn}$ is 360 times; $\mathrm{Co}, \mathrm{Cd}, \mathrm{Cs}$ are $34-55$ times greater than that of the world mean values (Table 3 ).

The downstream evolution of TDS and trace elements along the Modonkul river illustrates conservative and nonconservative behavior. Along the Modonkul, TDS shows the largest variations 
o4.7-fold; $\mathrm{SO}_{4}{ }^{2-}$-ions 24.7-fold; $\mathrm{Na}^{+}$-ions 14.7-fold; $\mathrm{F}^{-}$-ions 24.7-fold. Trace elements show high enhancement for Be-by 19, Mn-by 78, Co-by 37, Zn-by 19, Cd-by 58 times. This significant enhancement of dissolved metals can be related to the occurrence of ore deposits in the river basin. While major elements show the lowest variability, trace elements show a 57-fold increase of manganese and cadmium. A steady increase (between 1.5 and 7 times) in the concentrations of $\mathrm{Li}, \mathrm{Al}, \mathrm{Ti}, \mathrm{Fe}, \mathrm{Ni}$, $\mathrm{Cu}, \mathrm{As}, \mathrm{Rb}, \mathrm{Mo}, \mathrm{Sb}, \mathrm{Ba}, \mathrm{W}, \mathrm{Re}$, and $\mathrm{U}$ was observed.

Thus, trace-element concentrations in the Modonkul river span 6-7 orders of magnitude. In the dissolved load, the preferential dissolution of the different types of lithology or mineral can cause large variations in trace-element abundances in the river. A rough classification of trace element mobility in river water can be drawn. The first group comprises the highly mobile elements, with mobility more than 10-100 times greater than that of the world mean values. It consists of Be, Zn, Co, Cd, Cs. The following group of moderately mobile elements includes $\mathrm{Li}, \mathrm{Cr}, \mathrm{Ti}, \mathrm{Mn}, \mathrm{Co}, \mathrm{Ni}, \mathrm{Cu}, \mathrm{Rb}, \mathrm{Sr}, \mathrm{Y}, \mathrm{Zr}$, $\mathrm{Mo}, \mathrm{Sb}, \mathrm{Ba}, \mathrm{Re}, \mathrm{Pb}, \mathrm{U}$. Their mobility is close to or is $\sim 2-10$ times greater than that of the world mean values. Finally, the last category, the most immobile elements, includes Al, V, Sc, Fe, Ga, As, Hf, Ta, W, Th, with mobility less than that of the world mean values. The dissolved concentrations of $\mathrm{Al}$ and Fe are close to or lower with the world values in the river flow. In the article [14], it was shown that in the fraction $<5 \mu \mathrm{m}, \mathrm{Al}$ concentrations predominantly correlate with Fe hydroxides. The dissolved concentrations of $\mathrm{Al}$ and Fe depend on the concentration of suspended matter; their size distribution, as well, is related to weathering regimes in the river basin. It is known that the vast majority of total Fe $(>90 \%)$ is transported by suspended matter in particulate concentrations [15]; this was observed in the river Modonkul, as it is shown in the next section.

The dissolved Mn concentration is more variable, so, at the upper river, it reaches $6.7 \mu \mathrm{g} \cdot \mathrm{L}^{-1}$, but at the mouth, it rises up to $483 \mu \mathrm{g} \cdot \mathrm{L}^{-1}$. This is mainly due to rapid oxidation-reduction processes. The manganese variations are consistent with redox changes within the river system. Literature data also show a large variation in dissolved manganese. For example, in the article, the largest amplitude of dissolved concentrations is observed for manganese (50 times increase with water discharge increase) and iron (8-fold variation); elements such as cadmium (8-fold) and cobalt (4-fold) show increases [16].

Among the anionogenic elements $\mathrm{F}, \mathrm{Mo}, \mathrm{Sb}, \mathrm{As}, \mathrm{V}, \mathrm{Cr}$, the concentrations of $\mathrm{F}$, Mo, Sb are two or more times greater than that of the world mean values for river water, which mainly is due to their enrichment from ore deposits the river basin. The dissolved concentrations of As, V, Cr are almost close or no more than 1.2-2 times that of the world mean values.

Alkali and alkaline earth trace elements are correlated to either sodium, calcium, or TDS in the river. Alkali Li, Rb noticeably migrate, their concentrations increase by a factor of 3-7 times between the upper part and mouth of the river. The dissolved concentration of alkaline-earth elements Sr, Ba increase no more than 1.6-1.9 times along the river. Their concentrations are strongly positively correlated with major elements and $\mathrm{pH}$. Modokul river, being much influenced by carbonate dissolution, has high $\mathrm{pH}$ and alkalinity values. Like beryllium, caesium has a behavior that contrasts with that of the other alkali elements. The greater dissolved Cs concentration is related to its higher release from the widespread acidic effusives.

The concentrations of lithophilic elements $\mathrm{Ti}, \mathrm{Zr}, \mathrm{Nb}, \mathrm{Y}, \mathrm{Hf}$ do not practically change when moving downstream. The dissolved concentrations $\mathrm{Zr}, \mathrm{Y}$ are 4-9 times greater; $\mathrm{Ti}, \mathrm{Nb}$, Hf are close to that of the world mean values.

\subsection{Distribution of Heavy Metals.}

Tables 4 and 5 show the dissolved and particulated contents of the heavy metals in the sampling sites.

The inflow of acid mine water of the Kholtosonskoe deposit and sludge from mine tailings to the Modonkul river worsened the pollution of an already contaminated area. The main polluting agents of the spillage were heavy metals. The pyritic wastes from mining activities arrive from the affluent Inkur river. This pollution source contained significant amounts of heavy metals (e.g., $\mathrm{Zn}, \mathrm{Pb}, \mathrm{Mn}, \mathrm{Cu}$, 
Cd) present as sulfides, and provided a low $\mathrm{pH}$ media that makes metallic forms readily available and, therefore, easy to propagate throughout the river basin [17-20].

Table 4. The concentration of dissolved heavy metals $\left(\mu \mathrm{g} \cdot \mathrm{L}^{-1}\right) ; n=15$-number of samples.

\begin{tabular}{cccccccc}
\hline Site & $\mathbf{F e}$ & $\mathbf{M n}$ & $\mathbf{N i}$ & $\mathbf{C u}$ & $\mathbf{Z n}$ & $\mathbf{C d}$ & $\mathbf{P b}$ \\
\hline M1 & $\frac{15.9-56.8}{30.4}$ & $\frac{4.7-9.4}{7.7}$ & $\frac{1.7-3.2}{2.3}$ & $\frac{1.9-9.2}{7.6}$ & $\frac{7.3-29.5}{11}$ & $\frac{0.8-1.2}{1.1}$ & $\frac{0.7-1.5}{1.1}$ \\
M2 & $\frac{5.1-36.2}{26.4}$ & $\frac{82.0-165}{126}$ & $\frac{1.2-8.9}{5.8}$ & $\frac{7.6-21.3}{15.2}$ & $\frac{120-273}{186}$ & $\frac{1.1-3.4}{2.8}$ & $\frac{1.1-2.9}{0.9}$ \\
M3 & $\frac{32-63.4}{48}$ & $\frac{8.2-24.8}{16.4}$ & $\frac{1.7-5.6}{2.5}$ & $\frac{4.3-12.6}{9.4}$ & $\frac{15.8-45}{32}$ & $\frac{0.8-1.2}{1.0}$ & $\frac{0.8-1.5}{1.1}$ \\
M4 & $\frac{14-38.7}{27.6}$ & $\frac{141.8-352}{248}$ & $\frac{2.1-3.9}{2.6}$ & $\frac{9.6-28.1}{20.5}$ & $\frac{256-483}{367}$ & $\frac{2.1-5.7}{3.8}$ & $\frac{1.8-4.4}{3.2}$ \\
M5 & $\frac{16.8-46.3}{38.6}$ & $\frac{12.8-53.2}{40.9}$ & $\frac{1.2-2.9}{1.8}$ & $\frac{3.4-12.8}{8.6}$ & $\frac{30.3-123}{72}$ & $\frac{1.2-3.2}{2.4}$ & $\frac{1.1-2.6}{1.8}$ \\
M6 & $\frac{15.3-28.9}{22.5}$ & $\frac{87.3-254}{198}$ & $\frac{1.8-5.8}{3.2}$ & $\frac{8.7-21.9}{16.6}$ & $\frac{115-192}{153}$ & $\frac{1.1-5.2}{3.2}$ & $\frac{1.0-3.2}{2.4}$ \\
M7 & $\frac{21.4-62.7}{52.7}$ & $\frac{315-572}{483}$ & $\frac{1.7-6.1}{3.5}$ & $\frac{12.5-32.8}{22.5}$ & $\frac{148-321}{216}$ & $\frac{2.8-6.1}{4.4}$ & $\frac{1.2-3.5}{2.8}$ \\
\hline
\end{tabular}

Note. In the numerator-the range of concentrations; in the denominator-the mean value.

Table 5. The heavy metal concentrations in suspended phase of river Modokul $\left(\mu \mathrm{g} \cdot \mathrm{L}^{-1}\right), n=15$-number of samples.

\begin{tabular}{cccccccc}
\hline Site & $\mathbf{F e}$ & $\mathbf{M n}$ & $\mathbf{N i}$ & $\mathbf{C u}$ & $\mathbf{Z n}$ & $\mathbf{C d}$ & $\mathbf{P b}$ \\
\hline M1 & $\frac{156-347}{259}$ & $\frac{23.2-41.3}{38.3}$ & $\frac{1.1-3.6}{1.9}$ & $\frac{3.6-13.2}{9.8}$ & $\frac{45-82}{67}$ & $\frac{0.6-1.4}{0.8}$ & $\frac{1.2-2.1}{1.6}$ \\
M2 & $\frac{124-248}{185}$ & $\frac{97-151}{126}$ & $\frac{3.6-8.2}{5.3}$ & $\frac{9.2-34}{15}$ & $\frac{134-186}{152}$ & $\frac{16.8-32.8}{24}$ & $\frac{3.5-10.7}{6.2}$ \\
M3 & $\frac{476-812}{684}$ & $\frac{272-506}{386}$ & $\frac{2.3-6.4}{4.2}$ & $\frac{15-29}{21}$ & $\frac{183-262}{214}$ & $\frac{19.2-42.7}{32}$ & $\frac{5.8-12.6}{7.2}$ \\
M4 & $\frac{342-722}{575}$ & $\frac{265-431}{353}$ & $\frac{2.8-7.2}{5.4}$ & $\frac{11-26}{18}$ & $\frac{98-167}{129}$ & $\frac{12.1-23.3}{17}$ & $\frac{4.2-9.2}{6.4}$ \\
M5 & $\frac{491-832}{692}$ & $\frac{177-348}{215}$ & $\frac{2.2-6.7}{4.8}$ & $\frac{12-29}{21}$ & $\frac{116-173}{146}$ & $\frac{11.5-24.2}{18}$ & $\frac{3.6-8.9}{5.7}$ \\
M6 & $\frac{923-1280}{1012}$ & $\frac{198-314}{268}$ & $\frac{2.8-7.9}{5.1}$ & $\frac{8.6-21.4}{14}$ & $\frac{102-172}{137}$ & $\frac{2.7-10.5}{6.2}$ & $\frac{6.7-14.5}{9.8}$ \\
M7 & $\frac{1006-1365}{1238}$ & $\frac{243-376}{315}$ & $\frac{2.3-6.8}{4.5}$ & $\frac{11-20.4}{17}$ & $\frac{128-217}{186}$ & $\frac{3.6-12.7}{8.4}$ & $\frac{4.6-13.8}{8.6}$ \\
\hline
\end{tabular}

Note. In the numerator-the range of concentrations; in the denominator-the mean value.

The mixing zone of natural river water with of acid mine water and tributary Incur presents oxidation-reduction processes and an increasing $\mathrm{pH}$; an alkaline barrier is created. These mixing processes can lead to change in the behavior of heavy metals in dissolved and particulated loads. Dissolved ferrous iron, with increasing $\mathrm{pH}$ and dissolved oxygen, oxidizes and precipitates at the bottom in the form of hydroxides. In the site M2, the dissolved iron concentration is 1.15 times less than at the upper site M1. At the same time, the dissolved concentrations Mn, $\mathrm{Zn}$ increase by a factor of 16-16.9, but $\mathrm{Ni}, \mathrm{Cu}, \mathrm{Cd}$ - by a factor of 2-2.5. In the site $\mathrm{M} 3$, the dissolved concentrations $\mathrm{Fe}, \mathrm{Cu}$ exceed natural background levels by a factor of 1.2-1.5, with the exception of a $2-3$-fold increase for manganese and zinc. After the confluence of the Inkur river (site M4), the dissolved concentrations $\mathrm{Cu}, \mathrm{Pb}, \mathrm{Cd}$ increase by a factor of 2.6-3 times; $\mathrm{Mn}, \mathrm{Zn}-33$ times than that natural background levels (site M1). By contrast, the dissolved Fe concentration decreases by a factor of 1.1. It should be noted that the behavior of Fe differs from that for $\mathrm{Mn}$ and other metals. The amplitude variability of the dissolved Fe concentration is not exceeded by the large variation in the natural background level; probably, this is due to hydrolysis and sedimentation of hydroxides in the mixing zone (Table 4, Figure 5a,b). 


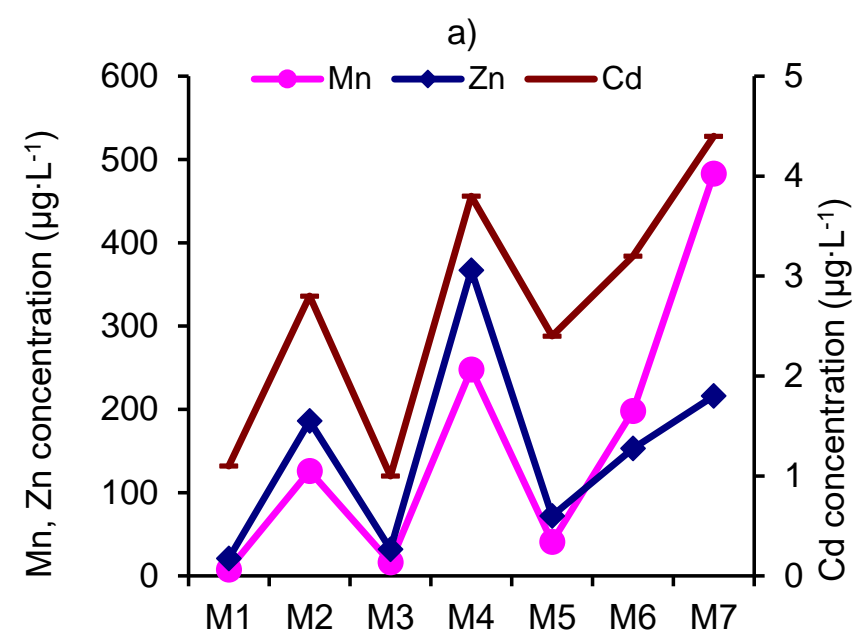

sampling site

b)

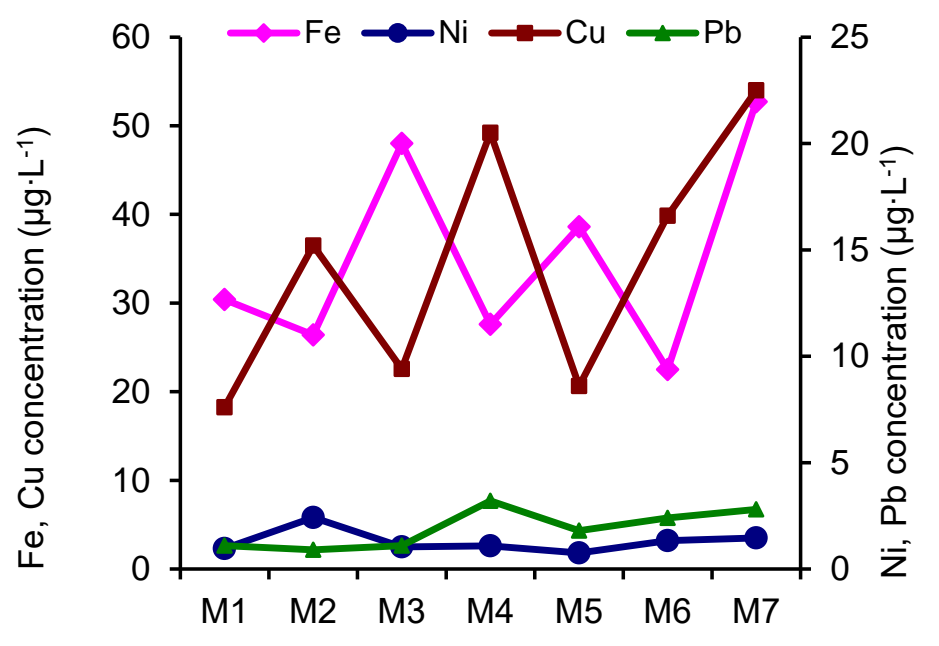

sampling site

Figure 5. Variation of the dissolved $\mathrm{Mn}, \mathrm{Zn}, \mathrm{Cd}(\mathbf{a}), \mathrm{Fe}, \mathrm{Ni}, \mathrm{Cu}, \mathrm{Pb}(\mathbf{b})$ concentrations in the sampling sites.

Compared with mine water, the decrease of the concentration $\mathrm{SO}_{4}{ }^{2-}$ anions and the present alkaline barrier in the river limits the possibility of complexation oxidizing sulfides $\mathrm{Fe}, \mathrm{Cu}, \mathrm{Zn}, \mathrm{Pb}, \mathrm{Cd}$. The sedimentation of $\mathrm{Fe}, \mathrm{Al}$, and $\mathrm{Mn}$ hydroxides and the sorption by them complexing heavy metals reduce their concentration in the river water [21-24].

As noted above, the dissolved content of heavy metals in the site M7 exceeds the world river mean value by a factor of $\mathrm{Fe}-0.8, \mathrm{Mn}-15, \mathrm{Zn}-360, \mathrm{Cu}-15, \mathrm{~Pb}-12, \mathrm{Cd}-55$ times. The behavior of heavy metals not only depends on the sources, but it is also strongly controlled by the soil and in-stream processes, particularly through aqueous (organic and inorganic) complexation and reactions with solids.

The river transports material, both in dissolved form and as a solid load (suspended matter and bottom sands). The dominant form of transport of trace elements per liter of river water depends on both the mobility of the elements in the weathering than the transport process and on the amount of solids transport annually by the river. In rivers, particles encompass a wide range of chemical and mineralogical composition (biological debris, organic substances, oxyhydroxides, clays, rock fragments). These sediments are either produced in situ or are generally derived from erosion of soils [25-29].

The amount of suspended sediments in the upper of the river Modonkul (site M1) fluctuates from 1.6 to $26.8 \mathrm{mg} \cdot \mathrm{L}^{-1}$; in the next site $\mathrm{M} 2$-from 56.3 to $158.8 \mathrm{mg} \cdot \mathrm{L}^{-1}$. The concentration of metals 
associated with suspended sediments increases by a factor of 1.5 to 3.8 for $\mathrm{Mn}, \mathrm{Cu}, \mathrm{Ni}, \mathrm{Zn}, \mathrm{Pb}$, and 30 for Cd between site M2 and site M1. In the site M1, a significant fraction of heavy metals is transported in the dissolved load. Conversely, in the site M2, the most heavy metals are transported predominantly in a solid form (Table 5, Figure 6a,b). This observed effect can be interpreted as a dilution of pollution by the natural erosion of uncontaminated soil particles at high water discharges.

a)

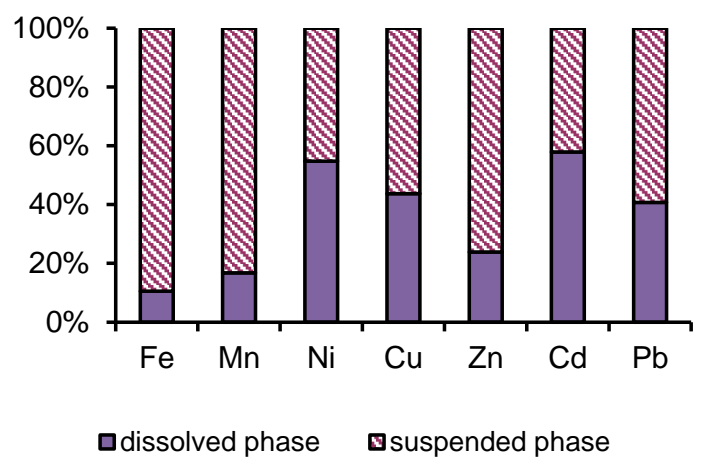

b)

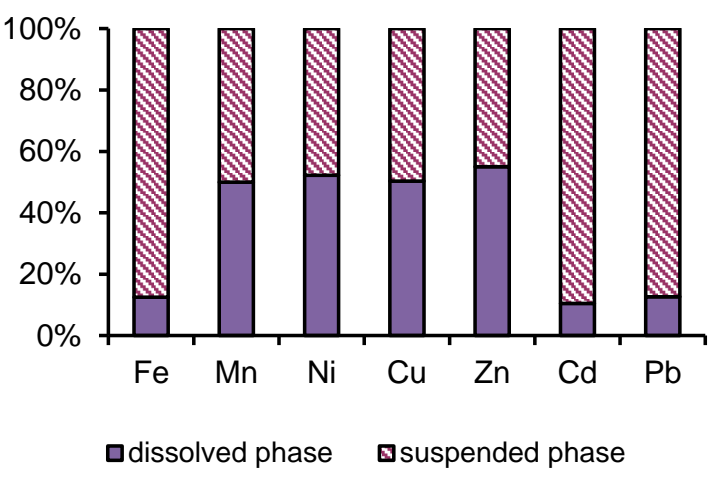

Figure 6. Variation of dissolved and suspended forms of migration heavy metals in the sampling sites M1(a) and M2 (b).

Iron, like manganese and other metals, can exist in more than one oxidation state. The solubility of such elements in aquatic systems depends on the concentration of oxygen, or, more generally, on the redox state of the fluvial system. Most often, running waters are oxygenated, but anoxic conditions can prevail locally in sites with inflowing affluent streams like Inkur, mine water from the Kholtosonskoe deposit, and urban wastewaters from Zakamensk city.

The uptake of heavy metals by surfaces is due to the presence of complexing sites similar to those complexing ions in solution (e.g., $\mathrm{OH}, \mathrm{COOH}$ groups). The percentage of cation adsorption on $\mathrm{FeOOH}$ increases with increasing $\mathrm{pH}$. Conversely, the adsorption of anions decreases with increasing $\mathrm{pH}$ [30]. The association of a ligand in solution, heavy metal in solution, and a surface can lead to the formation of ternary surface complexes. Finely divided hydrous oxides of iron, aluminum, manganese, and silicon are dominant sorbents in rivers. Because the stability of manganese and iron oxides is redox-sensitive, the behavior of other heavy metals controlled by adsorption on these surfaces is expected to vary with the redox state.

In the case river Modonkul, the heavy metals concentrations in the suspended phase increase by a factor of $\mathrm{Fe}-4.7, \mathrm{Mn}-8.2, \mathrm{Ni}-2.3, \mathrm{Cu}-1.7, \mathrm{Zn}-2.7, \mathrm{Cd}-10.5, \mathrm{~Pb}-5.3$ between sites $\mathrm{M} 7 \mathrm{and} \mathrm{M} 1$ (Table 5, Figure 7a,b). The dissolved concentration of heavy metals increases by a factor of Fe-1.7, $\mathrm{Mn}-62.7, \mathrm{Cu}-2.9, \mathrm{Ni}-1.5, \mathrm{Zn}-19, \mathrm{Cd}-4, \mathrm{~Pb}-2.5$ times between the mouth and the upper part 
of the river. Significant discrepancy in enhancement of dissolved $\mathrm{Mn}, \mathrm{Zn}$ and Cd concentrations are related in the redox state in the mouth of river. This is consistent with the findings of many authors [31]. The variations in redox conditions affect not only the dissolved concentrations of iron and manganese but also the concentrations of elements sorbed onto iron and manganese oxides, such as zinc, copper, and cadmium in waters.

a)

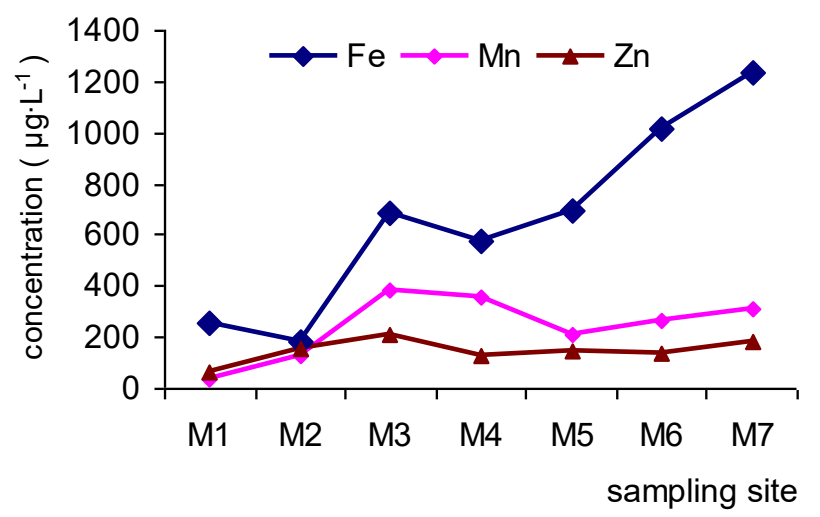

b)

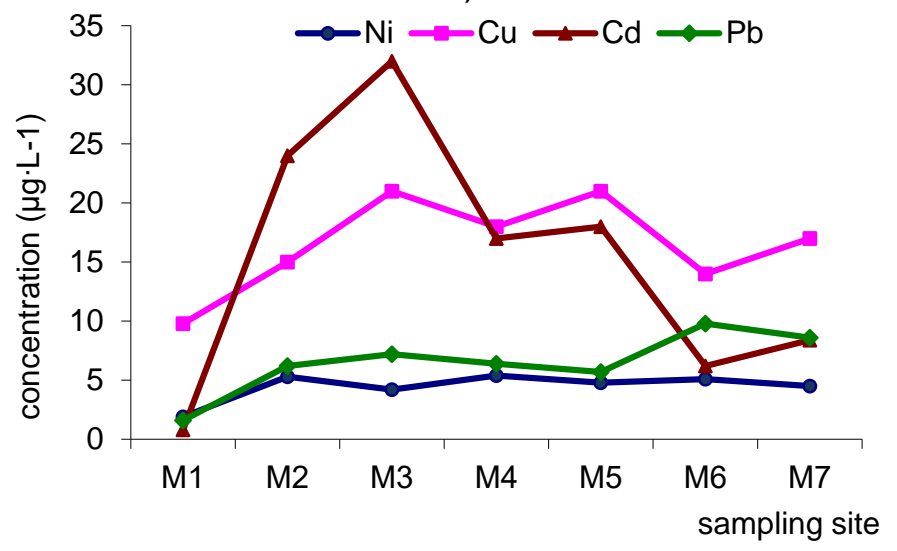

Figure 7. Variation of suspended phase $\mathrm{Fe}, \mathrm{Mn}, \mathrm{Zn}(\mathbf{a}), \mathrm{Ni}, \mathrm{Cu}, \mathrm{Cd}, \mathrm{Pb}(\mathbf{b})$.

Thus, the mine waters of the Kholtosonskoe deposit and the tributary of the river Inkur are sources of ore technogenic elements into Modonkul water runoff. Their acidic waters differ from the natural water of the river. River particulates have the potential of regulating heavy metal input to aquatic systems from pollution. The $\mathrm{pH}$ values and dissolved oxygen cycles could change the uptake of heavy metals on suspended iron and manganese oxides, and the mechanism of removing it from the water. As a result, ore or heavy metals are removed in two ways: the river Modonkul's water flow and sedimentation of suspended material at the bottom.

\subsection{Rare Earth Elements}

Data of the mean concentrations REEs in the upper part (site M1) and mouth (site M7) of Modonkul river and the mine of the Kholtosonskoe deposit are compiled in Table 6. Parameters such as major solute concentrations, dissolved organic carbon, and $\mathrm{pH}$ appear to control the REE concentrations in river water. In the case of the Modonkul river, in the mouth (site M7), major solute concentrations are higher, and TDS is greater by 4 times than in upper part of river (site M1). The sum REE concentrations decrease by a factor 3.9 between the sites M1 and M7. The lowest concentrations of REEs are found in 
the site M7, having the highest $\mathrm{pH}$. Thus the concentrations of REEs negatively correlated with major elements and $\mathrm{pH}$ values.

Table 6. The mean concentration REEs in the upper part (site M1)and mouth (site M7) of the Modonkul river and the mine of the Kholtosonskoe deposit $\left(\mu \mathrm{g} \cdot \mathrm{L}^{-1}\right), n=15$ number of samples.

\begin{tabular}{ccccc}
\hline Element & M1 & M7 & $\begin{array}{c}\text { Mine Water } \\
\text { Kholtosonskoe } \\
\text { Deposit }\end{array}$ & $\begin{array}{c}\text { Detection } \\
\text { Limit }\end{array}$ \\
\hline $\mathrm{La}$ & 0.3399 & 0.0659 & 143.08 & 0.011 \\
$\mathrm{Ce}$ & 0.2466 & 0.1029 & 340.8 & 0.0022 \\
$\mathrm{Pr}$ & 0.0952 & 0.0166 & 42.71 & 0.0003 \\
$\mathrm{Nd}$ & 0.4289 & 0.0936 & 215.48 & 0.0020 \\
$\mathrm{Sm}$ & 0.0875 & 0.0168 & 56.09 & 0.0003 \\
$\mathrm{Eu}$ & 0.0207 & 0.0099 & 16.94 & 0.0004 \\
$\mathrm{Gd}$ & 0.1071 & 0.0229 & 62.33 & 0.0003 \\
$\mathrm{~Tb}$ & 0.013 & 0.0035 & 10.75 & 0.0009 \\
$\mathrm{Dy}$ & 0.0612 & 0.0183 & 71.34 & 0.0002 \\
$\mathrm{Ho}$ & 0.0122 & 0.0036 & 12.52 & 0.0003 \\
$\mathrm{Er}$ & 0.0398 & 0.0122 & 38.98 & 0.0006 \\
$\mathrm{Tm}$ & 0.0052 & 0.0016 & 4.67 & 0.0001 \\
$\mathrm{Lu}$ & 0.0059 & 0.0016 & 4.31 & 0.0005 \\
$\Sigma \mathrm{LREE}$ & 1.22 & 0.31 & 815.10 & - \\
$\Sigma \mathrm{HREE}$ & 0.24 & 0.06 & 204.90 & - \\
$\Sigma \mathrm{REE}$ & 1.46 & 0.37 & 1020.00 & - \\
$\mathrm{Ce} / \mathrm{Ce}$ & 0.30 & 0.68 & 0.95 & - \\
$\mathrm{Eu} / \mathrm{Eu}$ & 0.93 & 2.17 & 1.25 & - \\
$(\mathrm{La} / \mathrm{Yb})_{\mathrm{N}}$ & 0.97 & 0.80 & 0.42 & \\
\hline
\end{tabular}

The value of the ratio $(\mathrm{La} / \mathrm{Yb})_{\mathrm{N}}$ equals to $0.80-0.97$, which characterizes the enrichment by LREE river water. In mine water, this value is 0.42 , which indicates the predominant enrichment by HREE. Normalized profiles of REEs concentrations in the site M1 are characterized by a negative cerium anomaly $\mathrm{Ce} / \mathrm{Ce}^{*}=0.30-0.68$. At the mouth (site $\mathrm{M7}$ ), a positive europium anomaly $\mathrm{Eu} / \mathrm{Eu}^{*}=2.17 \mathrm{is}$ clearly manifested. The normalized profile of mine water records a positive europium anomaly $\mathrm{Eu} / \mathrm{Eu}^{*}$ $=1.25$ and the absence of a cerium anomaly Ce/ $\mathrm{Ce}^{*}=0.95$ (Table 6 ). The inflow of mine water into the Modonkul leads to the formation of REE composition with negative cerium and positive europium anomalies (Figure 8).

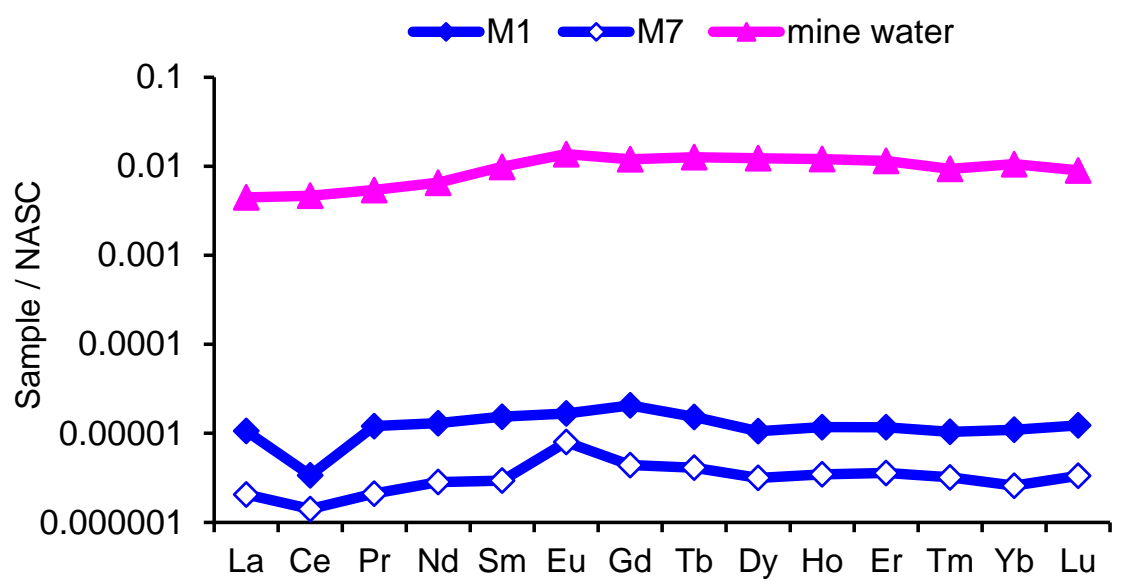

Figure 8. Normalized distribution of rare-earth elements in the river water Modonkul in the sites M1 and M7 and the mine water of the Kholtosonskoe deposit. 
Thus, the sources of REE in the water Modonkul river are lanthanides of basin rocks and the mine waters of the Kholtosonskoe tungsten deposit.

\section{Conclusions}

The river is an open and dynamically changing aquatic system. The impact of inflowing tributary and mine water on the chemical composition occurs at a distance along the length of the river. Significant variations in chemical composition indicate the complex effect of mining waste combined with hydrological and climatic factors.

(1) Along the river, the chemical type of water changes from bicarbonate to sulfate across the sulfate-bicarbonate or bicarbonate-sulfate class and from calcium-magnesium across sodium-calcium-magnesium reverse calcium-magnesium group. TDS increase by a factor of 4.0 to 4.7 between in the upper part and mouth of the river.

(2) Trace-element concentrations in Modonkul river span 6-7 orders of magnitude. A rough classification of trace element mobility in river water can be drawn. The first group comprises the highly mobile elements, with mobility more than 10-100 times greater than that of the world mean values. It consists of $\mathrm{Be}, \mathrm{Zn}, \mathrm{Co}, \mathrm{Cd}, \mathrm{Cs}$. The following group of moderately mobile elements includes $\mathrm{Li}, \mathrm{Cr}, \mathrm{Ti}, \mathrm{Mn}, \mathrm{Co}, \mathrm{Ni}, \mathrm{Cu}, \mathrm{Rb}, \mathrm{Sr}, \mathrm{Y}, \mathrm{Zr}, \mathrm{Mo}, \mathrm{Sb}, \mathrm{Ba}, \mathrm{Re}, \mathrm{Pb}, \mathrm{U}$. Their mobility close to or is $\sim 2-10$ times greater than that of the world mean values. Finally, the last category, the most immobile elements, includes $\mathrm{Al}, \mathrm{V}, \mathrm{Sc}, \mathrm{Fe}, \mathrm{Ga}, \mathrm{As}, \mathrm{Hf}, \mathrm{Ta}, \mathrm{W}$, Th with mobility less than that of world mean values. The dissolved concentrations of $\mathrm{Al}$ and $\mathrm{Fe}$ are close to or lower with the world mean values in the river flow. The concentrations of lithophilic elements Ti, Zr, Nb, Y, Hf practically do not change when moving downstream. The dissolved concentrations $\mathrm{Zr}, \mathrm{Y}$ are 4-9 times greater, and $\mathrm{Ti}, \mathrm{Nb}, \mathrm{Hf}$ are close to that of world mean values.

(3) The mine of the Kholtosonskoe deposit and tributary of the river Inkur are sources of ore technogenic elements into the environment. In the mixing zone, the $\mathrm{pH}$ increases, and an alkaline barrier is created. The inflow of mine water and tributary Inkur increases the turbidity of water in the river Modonkul. The river transports material, both in dissolved form and as solid load (suspended matter and bottom sands). Hydrous oxides of iron, aluminum, manganese, and silicon are dominant sorbents in rivers. The $\mathrm{pH}$ values and dissolved oxygen cycles could change the uptake of heavy metals on suspended iron and manganese oxides and the mechanism of removing it from the water. River particulates have the potential of regulating heavy metal input to aquatic systems from pollution. The ore elements or heavy metals are removed from water by two ways: by the runoff of Modonkul and sedimentation of suspended material at the bottom.

(4) Sources of REEs in the river Modonkul are lanthanides from basin rocks and the mine waters of the Kholtosonskoe tungsten deposit. The inflow of mine water into the Modonkul river leads to the REEs composition with negative cerium and positive europium anomalies.

Author Contributions: Conceptualization, Z.I.K.; Data curation, A.M.P.; Investigation, Z.I.K., A.M.P., O.K.S., E.G.P., D.I.Z., S.G.D. and V.V.D.; Methodology, Z.I.K. and O.K.S.; Project administration, D.I.Z.; Visualization, S.G.D. and V.V.D.; Writing - review \& editing, E.G.P. All authors have read and agreed to the published version of the manuscript.

Funding: This study was performed within the state tasks of GIN SB RAS. The investigations has been conducted within the fundamental research framework of the GIN SB RAS (reg. number AAAA-A17-117021310076-3). This work was financially supported by a grant from the Russian Foundation for Basic Research (Siberia), project no. 18-45-030003 (principal investigator A.M. Plyusnin).

Acknowledgments: The authors thank the reviewers for constructive critical review comments that led us to improve the manuscript. We would like to thank researcher S.S.Sanzhanova for valuable technical support.

Conflicts of Interest: The authors declare no conflict of interest. 


\section{References}

1. Gordienko, I.V.; Gorokhovsky, D.V.; Smirnova, O.K.; Lantseva, V.S.; Badmatsyrenova, R.A.; Orsoev, D.A. Dzhida ore district: geology, structural and metallogenic regionalization, genetic types of ore deposits, geodynamic conditions of their formation, forecast, and outlook for development. Geol. Ore Depos. 2018, 60, 3-37. [CrossRef]

2. Damdinova, L.B.; Damdinov, B.B.; Huang, X.-W.; Bryansky, N.V.; Khybanov, V.B.; Yudin, D.S. Age, conditions of formation and fluid composition of the pervomaiskoe molybdenum deposit (Dzhidinskoe ore field, southwestern Transbaikalia, Russia). Minerals 2019, 9, 572. [CrossRef]

3. Khodanovich, P.Y.; Smirnova, O.K. Tungsten-Bearing Berezites And A Local Forecast of Mineralization; Nauka: Novosibirsk, Russia, 1991; p. 208.

4. Smirnova, O.K.; Plyusnin, A.M. Dzhidinsky Ore District (Environmental Problems); Buryat Science Center SB RAS: Ulan-Ude, Russia, 2013; p. 181.

5. Gordienko, I.V.; Filimonov, A.V.; Minina, O.R.; Klimuk, V.S.; Elbaev, A.L.; Gornova, M.A.; Medvedev, A.Y.; Tomurtogoo, O. Dzhida island-arc system in the paleoasian ocean: Structure and main stages of vendian-paleozoic geodynamic evolution. Russ. Geol. Geophys. 2007, 48, 91-106. [CrossRef]

6. Reyf, F.G. Ore-Forming Potential of Granites and Conditions for Its Realization; Nauka: Moscow, Russia, 1990; p. 180. (In Russian)

7. Ontoev, D.O. Mineralization Staging And Zoning of Transbaikalian Deposits; Nauka: Moscow, Russia, 1974; p. 241. (In Russian)

8. Integrated Water Management. In The Selenge Basin River. Report of Project "Selenga Basin River"; Sovintervod: Moscow, Russia, 2004; p. 556.

9. State Control of Water Quality. Handbook of The Technical Committee For Standardization, 2nd ed.; IPK Standards Publishing House: Moscow, Russia, 2003; p. 776. (In Russian)

10. Alekin, O.A. Fundamental of Hidrochemistry; Gidrometeoizdat: Leningrad, Russia, 1970; p. 444.

11. Gibbs, R. Mechanisms controlling world water chemistry. Science 1970, 170, 1088-1090. [CrossRef] [PubMed]

12. Edmond, Y.M.; Spivack, A.; Grant, B.C.; Hum, H.; Chen, Z.X.; Chen, S.; Zong, X.S. Chemical dynamics of the Changjiang estuary. Cont. Shelf Res. 1985, 4, 17-36. [CrossRef]

13. Gaillardet, J.; Viers, J.; Dupre, B. Trace elements in River Waters. In Surface And Ground Water: Treatise on Geochemistry Weathering And Soils; Drever, J.I., Turikan, K.K., Eds.; Elsevier: Berlin, Germany, 2003; Volume 5, pp. 225-272.

14. Pokrovsky, O.S.; Shott, J. Iron colloids/organic matter associated transport of major and trace elements in small boreal rivers and their estuarias (NW Russia). Chem. Geol. 2002, 190, 141-179. [CrossRef]

15. Shibata, H. Process Of Iron Transport From Terrestrial Ecosystem. In To River: Preliminary Analysis Of Spatial And Temporal Patterns Of Iron Concentrations In Amur River, Proceedings of the International Kyoto Symposium Representative Amur-Okhotsk Project, RIHN, Kyoto, Japan, 26 October 2011; Springer: Berlin, Germany, 2005; Volume 3, pp. 3273-3277.

16. Elbaz-Poulichet, F.; Seyler, P.; Maurice-Bourgoin, L. Trace element geochemistry in the upper Amazon drainage basin (Bolivia). Chem. Geol. 1999, 157, 319-334. [CrossRef]

17. Abrosimova, N.; Gaskova, O.; Loshkareva, A.; Edelev, A.; Bortnikova, S. Assessment of the acid mine drainage potential of waste rocks at the Ak-Sug porphyry Cu-Mo deposit. J. Geochem. Explor. 2015, 157, 1-14. [CrossRef]

18. Wei, X.; Wolfe, F.A.; Han, Y. Mine drainage characterization, treatment, modeling, and environmental aspect. Water Env. Res. 2014, 86, 1515-1534. [CrossRef]

19. Moncur, M.C.; Ptacek, C.J.; Blowes, D.W.; Jambor, J.L. Release, transport and attenuation of metals from an old tailings impoundment. Appl. Geochem. 2005, 215, 639-659. [CrossRef]

20. Lengke, M.F.; Davis, A.; Buckman, C. Improving management of potentially acid generating waste rock. Mine. Water Env. 2010, 29, 29-44. [CrossRef]

21. Flores, R.G.; Andersen, S.L.F.; Maia, L.K.K.; Jose, H.J.; Moreira, R.F.P.M. Recovery of iron oxides from acid mine drainage and their application as adsorbent or catalyst. J. Env. Manag. 2012, 111, 53-60. [CrossRef] [PubMed] 
22. Meng, S.; Wang, H.; Liu, H.; Yang, C.; Wei, Y.; Hou, D. Evaluation of the ability of ferrihydrite to bind heavy metal ions: Based on formation environment, adsorption reversibility and ageing. Appl. Geochem. 2014, 45, 114-119. [CrossRef]

23. Komarek, M.; Vanek, A.; Ettler, V. Chemical stabilization of metals and arsenic in contaminated soils using oxides-a review. Env. Pollut. 2013, 172, 9-22. [CrossRef]

24. Servida, D.; Grieco, G.; De Capitani, L. Geochemical hazard evalution of sulfide-rich iron mines: The Rio Marina district (Elba Island, Italy). J. Geochem. Explor. 2009, 100, 75-89. [CrossRef]

25. Negrel, P.; Grosbois, C.; Klopppman, W. The labile fraction of suspended matter in the Loire River (France): Multi-element chemistry and isotopic (Rb-Sr and C-O) systematics. Chem. Geol. 2000, 166, 271-285. [CrossRef]

26. Schafer, J.; Blan, G. Relationship between ore deposits in river catchments and geochemistry of suspended matter from six rivers in southwest France. Sci. Total Environ. 2002, 298, 103-118. [CrossRef]

27. Kraus, U.; Wiegand, J. Long-term effects of the Aznalcollar mine spill-heavy metal content and mobility in soils and sediments of the Guadiamar River valley (SW Spain). Sci. Total Environ. 2006, 367, 855-871. [CrossRef]

28. Li, Y.L.; Hall, K.; Yuan, Y.; Mattu, G.; McCallun, D.; Chen, M. Mobility and bioavailibility of trace metals in the water-sediment system of the highly urbanizid brunette watershed. Water Air Soil Pollution. 2009, 197, 249-266. [CrossRef]

29. Riba, I.; DelValls, T.A.; Reynoldson, T.B.; Milani, D. Sediment quality in Rio Guadiamar (SW, Spain) after a tailing dam collapse: Contamination, toxicity and bioavailability. Environ. Int. 2006, 32, 891-900. [CrossRef]

30. Blowes, D.W.; Ptacek, C.J.; Jambor, J.L.; Weisener, C.C. The geochemistry of acid mine drainage. Treatise Geochem. 2003, 9, 149-204.

31. Kosoff, D.; Hudson-Edvards, K.A.; Dubbin, W.E.; Alfredsson, M.A. Incongruent weathering of Cd and Zn from mine tailings: A column leaching study. Chem. Geol. 2011, 281, 52-71. [CrossRef]

(C) 2020 by the authors. Licensee MDPI, Basel, Switzerland. This article is an open access article distributed under the terms and conditions of the Creative Commons Attribution (CC BY) license (http://creativecommons.org/licenses/by/4.0/). 